Vol. 1 No. 3 Desember 2021, e-ISSN : 2797-8842 | p-ISSN : 2797-9431

\title{
PENGEMBANGAN LEMBAR KERJA PESERTA DIDIK (LKPD) BERBASIS DISCOVERY BASED LEARNING (DBL) DILENGKAPI SOAL HIGHER ORDER THINKING SKILLS (HOTS) PESERTA DIDIK KELAS XI MAN KOTA SORONG
}

\author{
SUARNI \\ MAN Kota Sorong \\ Email : Suarni7467@gmail.com
}

\begin{abstract}
ABSTRAK
Penelitian dan pengembangan LKPD Bahasa Inggris berbasis $D B L$ yang dilengkapi soal HOTS pada materi Narrative Text telah direalisasikan sesuai dengan tahapan $R \& D$. Perolehan hasil penelitian LKPD berbasis $D B L$ disimpulkan sebagai berikut : 1). Hasil validasi terhadap LKPD Bahasa Inggris berbasis $D B L$ yang dilengkapi soal HOTS peserta didik Kelas XI MAN Kota Sorong yang dikembangkan menunjukkan hasil yang valid dengan persentase 78,33\% ditinjau dari aspek validitas isi, validitas format dan validitas bahasa yang digunakan di dalam LKPD. Validasi ini dilakukan oleh tiga orang validator yang terdiri atas dua orang dosen Bahasa Inggris dan satu orang guru bidang studi Bahasa Indonesia. 2). Hasil praktikalitas terhadap LKPD Bahasa Inggris berbasis $D B L$ yang dikembangkan menunjukkan hasil praktikalitas pendidik dan praktikalitas peserta didik menunjukkan hasil yang praktis dan sangat praktis dengan persentase berturut - turut 75,96 \% dan 91,18 \%. Uji praktikalitas dilakukan pada guru Bahasa Inggris dan peserta didik Kelas XI IPS MAN Kota Sorong.
\end{abstract}

Kata Kunci : Lembar Kerja Peserta Didik (LKPD), Discovery Based Learning (DBL) dan Higher Order Thinking Skills (HOTS).

\section{ABSTRACT}

Research and development of DBL-based English worksheets equipped with HOTS questions on Narrative Text material has been realized in accordance with the R\&D stages. The results obtained from the DBL-based LKPD research are concluded as follows: 1). The results of the validation of the DBL-based English LKPD equipped with HOTS questions for the students of Class XI MAN Sorong City which were developed showed valid results with a percentage of $78.33 \%$ in terms of content validity, format validity and language validity used in the LKPD. This validation was carried out by three validators consisting of two English lecturers and one Indonesian language teacher. 2). The results of the practicality of the DBL-based English LKPD that were developed showed the results of the practicality of educators and the practicality of students showing practical and very practical results with the percentages of $75.96 \%$ and 91.18\% respectively. Practicality tests were conducted on English teachers and students of Class XI IPS MAN Sorong City.

Keywords: Student Worksheet (LKPD), Discovery Based Learning (DBL) and Higher Order Thinking Skills (HOTS).

\section{PENDAHULUAN}

Pendidikan di abad ke-21 peserta didik ditantang untuk memiliki keterampilan hidup (Life skill). Life skill yang dimaksud adalah kecakapan hidup yang dilakukan oleh peserta didik dalam menemukan dan membangun pengetahuan sendiri. Pengetahuan yang dimiliki peserta didik sangatlah penting dalam menghadapi berbagai masalah dan pada akhirnya mampu menemukan solusi dari permasalahan tersebut. Untuk menemukan solusi dari pemasalahan yang dihadapi peserta didik, seorang guru perlu mengembangkan keterampilan yang dapat melatih dan membangun pengetahuan berpikir peserta didik. Adapun upaya guru dalam mengembangkan pengetahuan berpikir peserta didik dapat dilakukan dengan cara mengintegrasikan model atau media pembelajaran apapun yang dapat meningkatkan pengetahuan berpikir dan keterampilan yang dimiliki oleh peserta didik. (Katon Agung, dkk, $2018: 2)$. 
Media adalah sesuatu dari segala bentuk atau saluran yang dapat menyampaikan pesan dari sumber ke penerima pesan yang dapat merangsang pikiran, perhatian dan membangkitkan semangat peserta didik untuk mencapai keinginan dalam memperoleh pengetahuan, keterampilan dan pembentukan sikap sesuai dengan tujuan informasi (Nunuk, 2018 : 3). Penggunaan media pembelajaran yang tepat guna di dalam pembelajaran dapat memberikan motivasi dan antusias kepada peserta didik serta memberi kemudahan bagi peserta didik untuk memahami materi pembelajaran sehingga memudahkan tercapainya tujuan belajar. Namun fakta yang ditemukan dari hasil wawancara yang peneliti lakukan dengan guru mata pelajaran Bahasa Inggris Kelas XI IPS pada hari Selasa, 21 September 2021 di MAN Kota Sorong diperoleh informasi bahwa salah satu yang menjadi kendala dalam proses belajar mengajar di Kelas XI IPS MAN Kota Sorong adalah keterbatasan media pembelajaran berupa bahan ajar itu sendiri. Peserta didik hanya berpegang kepada buku paket yang disediakan di sekolah namun belum mencukupi secara menyeluruh sehingga ada dari peserta didik memakai 1 buku paket untuk 2 orang, lebih lanjut guru Bahasa Inggris mengatakan bahwa waktu yang digunakan dalam proses belajar mengajar Bahasa Inggris juga sangat terbatas.

Bahasa Inggris merupakan salah satu cabang sains yang besar perananya dalam kehidupan, terlebih dalam bidang ilmu pengetahuan dan teknologi yang berkembang pesat pada saat ini. Konsep - konsep dalam Bahasa Inggris itu sendiri merupakan hasil dari pengamatan dan penelitian terhadap berbagai fenomena alam semesta yang dipelajari melalui eksperimen, karena belajar Bahasa Inggris pada hakikatnya merupakan pengetahuan yang cara memperolehnya melalui olah pikir dan olah tangan (minds on and hands on). Sarana untuk mewujudkan minds on dan hands on pada pembelajaran Bahasa Inggris diantaranya adalah menyediakan bahan ajar yang memenuhi kebutuhan tersebut dan memperoleh informasi serta wawasan keilmuan. Bahan ajar salah satunya adalah Lembar Kerja Peserta Didik (LKPD) (Nuraini, $2018: 5$ )

Lembar Kerja Peserta Didik (LKPD) adalah salah satu sarana dalam membantu kegiatan pembelajaran dengan memberikan kemudahan dalam berinterakasi antara guru dan peserta didik yang efektif (Heny Sulistia, dkk, 2017 : 2). Sedangkan menurut Susantini LKPD dapat dijadikan sebagai wadah dalam mengembangkan keaktifan belajar peserta didik dan mampu meningkatkan kemampuan berpikir kreatif dalam menyelesaikan sebuah permasalahan yang dihadapi sekaligus menjadi evaluasi bagi guru (Katon Agung, dkk, 2018 : 2). Lebih lanjut Trianto (2011 : 223) menyatakan LKPD merupakan lembaran yang berisi tugas atau kegiatan yang harus dilakukan oleh peserta didik dalam mengupayakan pembentukan kemampuan dasar serta memaksimalkan pemahaman dalam pencapaian indikator tertentu, selain itu LKPD mampu mendorong peserta didik untuk mencari dan menemukan konsep secara mandiri dari materi yang sedang dipelajari (Dira Ayu Annisa, dkk, 2016 :130).

LKPD perlu dikembangkan dengan menggunakan model pembelajaran agar pembelajaran lebih terarah dan terstruktur sebab di dalam model pembelajaran terdapat langkah pembelajaran yang harus diikuti oleh peserta didik. Selain itu penggunaan model pembelajaran terlebih dahulu disesuaikan dengan tujuan yang hendak dicapai. Adapun model yang bisa melatih dan mengembangkan kemapuan berpikir peserta didik salah satunya adalah model Discovery Based Learning ( $D B L)$. Model $D B L$ adalah kegiatan belajar yang menyajikan kepada peserta didik untuk mencari dan menemukan terlebih dahulu terkait materi apa yang akan dipelajari dibawah panduan seorang guru. Ruseffendi dalam Risqi dan Samsul (2014:36) mengemukakan bahwa model $D B L$ adalah proses pembelajaran yang menekankan penemuan secara mandiri melalui bantuan seorang guru dalam memperoleh pengetahuan yang belum diketahui sebelumnya yang sudah direncanakan dan diatur dengan sedemikin rupa. Selain itu Mustami dan Adriantoni dalam Heny Sulistia, dkk (2017:3) menyatakan model DBL adalah model pembelajaran yang berpatokan pada aktivitas belajar peserta didik. Berdasarkan Permendikbud Nomor 65 tahun 2013 tentang Standar Proses menyatakan bahwa model pembelajaran yang mengimplementasikan kurikulum 2013 adalah model pembelajaran berbasis Discovery Based Learning (DBL) (Permendikbud, 2013 : 3). Dengan demikian peserta didik 
diharapkan bisa aktif untuk mendapatkan pengetahuan baru seperti memberi dugaan, memprediksi dan melakukan dengan bantuan seorang guru. Dengan demikian guru dapat memanfaatkan LKPD berbasis DBL sebagai wadah dalam melatih dan mengembangkan pengetahuan dan keterampilan peserta didik.

Di dalam jenjang pendidikan kemampuan berpikir tingkat tinggi/ Higher Order Thinking Skills (HOTS) sangatlah penting bagi peserta didik karena selain dari tuntutan kurikulum 2013 HOTS juga mampu membawa peserta didik untuk berfikir lebih luas terhadap materi yang dipelajarinya. Menurut Brookhart di dalam Syaiful dan Zainal (2018 : 79) HOTS adalah cara berpikir yang digunakan untuk mentransfer sebuah masalah dalammencari dan menemukan solusi dari permasalahan tersebut yang menggunakan proses berpikir kritis. Sedangkan menurut Smith di dalam Budsankom (2015:2640) HOTS merupakan cara berpikir yang dibekali dari berbagai keterampilan seperti menganalisis, mensintesis, penalaran baik berupa induktif maupun deduktif, mempertimbangkan, interpretasi, memberi penilaian serta menarik kesimpulan dalam memecahkan sebuah masalah. Berikutnya Canas di dalam Katon Agung, dkk (2018:2) mengemukakan bahwa HOTS itu mencakup cara berpikir yang aktif dan kreatif dalam menghadapi sebuah masalah yang bersifat umum, penuh ketidak pastian dan dilematis (pertanyaan).

Namun permasalahan yang ditemukan pada penelitian awal yang dilaksanakan di MAN Kota Sorong ditemukan dari hasil belajar yang peneliti lakukan terhadap peserta didik Kelas XI IPS MAN Kota Sorong secara umum menunjukkan bahwa level HOTS peserta didik Kelas XI IPS tergolong rendah. Hal tersebut dinyatakan karena peneliti melaksanakan kuis di akhir pembelajaran dengan memberikan 2 buah soal berupa HOTS kepada peserta didik untuk mengetahui sejauh manakah HOTS peserta didik dalam menyelesaikan soal yang diberikan. Dari soal kuis yang diberikan peneliti dapat melihat bahwa HOTS peserta didik belum tercapai. Berikut hasil kuis peserta didik Kelas XI IPS MAN Kota Sorong terhadap materi narrative text. Dari jawaban peserta didik, maka dapat diketahui bahwa masih rendahnya pengetahuan peserta didik dalam materi narrative text. Peserta didik belum bisa memahami dan menganalisis soal yang diberikan. peserta didik seharusnya memahami dan mengkaji terlebih dahulu narrative text apa saja yang diketahui soal sekaligus menganalisis maksud dari soal.

Berdasarkan observasi awal yang peneliti lakukan ditemukan beberapa permasalahan yaitu : 1) Peserta didik belum mempunyai bahan ajar berupa LKPD/LKS, karena peserta didik hanya berpegang pada buku paket sekolah dan itu pun masih belum mencukupi secara menyeluruh. 2) Masih rendah peminatan peserta didik dalam belajar Bahasa Inggris, dalam hal ini peneliti mengamati secara langsung dalam proses belajar mengajar dimana kurangnya kreatifitas belajar peserta didik dimana peserta didik hanya menampung dan mencatat materi yang diajarkan. Selain itu ketika diberikan sebuah soal sederhana, sedikit dari peserta didik yang mampu menjawab dan sebagian dari mereka masih mengharapkan jawaban dari teman. 3) Jika soal ditukar dengan cara yang berbeda peserta didik terlihat sulit dalam menganalisis dan kebanyakan diantara mereka yang bingung sehingga membuat peserta didik sering bertanya kepada guru tanpa mencoba terlebih dahulu terkait soal yang diberikan. Penelitian terdahulu yang berjudul "Penggunaan Metode Discovery Based Learning Untuk Meningkatkan Keaktifan Dan Kompetensi Peserta Didik Pada Mata Pelajaran Perawatan Kelistrikan Kendaraan Ringan Kelas XI TKR 3 Di SMK Negeri 2 Yogyakarta”. Diperoleh bahwa hasil terjadinya peningkatan kompetensi dan keaktifan belajar peserta didik melalui penerapan pembelajaran Discovery Based Learning (DBL). Dilihat dari kenaikan siklus I ke siklus II yang dilakukan diantaranya : (1) Meningkatnya keaktifan belajar peserta didik dari 40.13\% - 76.16\% (2) Meningkatnya rata - rata nilai ketuntasan belajar peserta didik dari 75.74\% - 87.33\% (3) Nilai ketuntasan belajar peserta didik pada kompetensi kognitif dari $67.74 \%$ - 93.33\%. Dengan demikian peneliti menyimpulkan bahwa pembelajaran berbasis $D B L$ sangat cocok dan bagus untuk diterapkan dalam pembelajaran karena mampu mengembangkan kompetensi dan keaktifan belajar peserta didik. (Doni Setiawan Pramono, $2018: 2$ )

Sejalan dengan itu Yuliani dalam Katon Agung, dkk (2018 : 2) menyatakan bahwa 
diantara berbagai model efektif pembelajaran yang dapat memberi dampak positif terhadap pemahaman dan HOTS peserta didik adalah $D B L$. Berlandaskan dari hasil penelitian di atas maka peneliti tertarik untuk mengembangkan sebuah bahan ajar berupa LKPD berbasis $D B L$ yang dilengkapi soal HOTS untuk mendukung keterlibatan peserta didik dalam belajar dan mampu mengembangkan aktivitas dan hasil belajar peserta didik. Materi yang digunakan dalam melakukan pengembangan ini terdiri dari 3 kompetensi dasar yaitu Membedakan fungsi sosial, struktur teks, dan unsur kebahasaan beberapa teks naratif lisan dan tulis dengan memberi dan meminta informasi terkaitlegenda rakyat, sederhana, sesuai dengan kontekspenggunaannya dan Menangkap makna secara kontekstual terkait fungsisosial, struktur teks, dan unsur kebahasaan teks naratif, lisan dan tulis sederhana terkait legenda rakyat dari kompetensi dasar yang menuntut peserta didik untuk menganalisis dan melakukan percobaan. Berdasarkan 2 kompetensi dasar tersebut dapat dilihat bahwa materi ini merupakan salah satu satu materi yang cocok digunakan untuk strategi $D B L$. Karena pada kompetensi dasarnya selain menganalisis yang merupakan indikator HOTS selanjutnya juga melakukan percobaan yang merupakan salah satu langkah - langkah dari strategi $D B L$. Selain itu materi yang dikembangkan juga merupakan salah satu materi yang konkrit dan banyak penerapanya dalam dunia nyata.

\section{METODE PENELITIAN}

Metode yang digunakan dalam pengembangan LKPD ini adalah penelitian dan pengembangan $(R \& D)$. Menurut Sugiyono (2012:407) penelitian dan pengembangan adalah penelitian yang dilakukan untuk mendapatkan suatu produk baru sekaligus melakukan pengujian keefektifan produk yang dihasilkan. Tujuan penelitian ini yaitu mengembangkan media pembelajaran Bahasa Inggris menggunakan LKPD berbasis $D B L$ dilengkapi soal HOTS peserta didik Kelas XI SMA/ MA dengan prosedur yang sistematis dan uji kelayakan baik dari segi media, materi dan kemenarikanya bagi peserta didik Model pengembangan dalam penelitian ini merujuk kepada Thiagarajan dan Semmel dalam Trianto (2009: 189) yaitu model 4-D yang terdiri atas 4 tahap yaitu define, design, develop and desseminate, sekarang diadaptasi pada 4-P yaitu pendefenisian, perancangan, pengembangan dan penyebaran. Tahap define (pendefinisian) berisi kegiatan memutuskan dan menetapkan suatu syarat dari pembelajaran yang meliputi tujuan dan batasan materi ajar. Tahap design (perancangan) berisi kegiatan merancang media pembelajaran. Tahap develop (pengembangan) berisi kegiatan menghasilkan produk media pembelajaran yang sudah direvisi berdasarkan kritik dan saran dari para ahli serta hasil uji coba data. Tahap desseminate (deseminasi) berisi kegiatan penggunaan produk yang sudah dikembangkan dan telah diuji cobakan dalam skala luas. Prosedur pelaksanaan model pengembangan yang akan peneliti lakukan hanya sampai tiga tahap yaitu : define, design, dan develop.

\section{HASIL DAN PEMBAHASAN}

LKPD Bahasa Inggris berbasis DBL yang dilengkapi soal HOTS peserta didik Kelas XI SMA/MA dirancang berdasarkan jenis penelitian $R \& D$ dengan menerapkan model 4-D (Four$D$ Models). Hasil yang perolehan penelitian ini dijabarkan sebagai berikut :Tahap pendefenisian ini menggambarkan tahap studi lapangan yang bertujuan untuk mengetahui sejumlah informasi dan masalah terkait proses pembelajaran di sekolah. Kegiatan ini dimulai dengan wawancara dengan guru Bahasa Inggris Kelas XI IPS MAN Kota Sorong, menganalisis silabus pembelajaran Bahasa Inggris Kelas XI IPS Semester I, menganalisis buku teks Bahasa Inggris yang dipakai guru Bahasa Inggris di Kelas XI IPS MAN Kota Sorong sebagai sumber belajar peserta didik, menganalisis kebutuhan peserta didik, serta mereview literatur tentang LKPD yang digunakan di sekolah tersebut. Berikut diuraikan hasil kegiatan pada tahap pendefenisian yaitu:

Menurut hasil yang diperoleh dari wawancara yang dilakukan dengan seorang guru Bahasa Inggris Kelas XI IPS di MAN Kota Sorong yaitu Bapak La Wali, S.Pd pada hari Selasa, 21 September 2021 diperoleh informasi kurikulum yang diterapkan dalam pembelajaran yaitu 
kurikulum 2013 revisi 2016. Selanjutnya pemakaian model pembelajaran yang dominan diterapkan adalah model ceramah dan diskusi kelompok. Lebih lanjut guru Bahasa Inggris mengatakan bahwa kecenderungan model pembelajaran yang digunakan di kelas sebenarnya tergantung dari model dan cara guru itu masing - masing artinya guru menggunakan model pembelajaran tidak terfokus hanya itu saja akan tetapi bagaimana pembelajaran itu terasa nyaman berlangsung secara efektif dan sejalan dengan waktu yang sudah ditetapkan. Sehingga memudahkan guru dan peserta didik untuk mencapai tujuan belajar itu sendiri. Namun yang menjadi permasalahan dalam proses pembelajaran yaitu keterbatasan waktu pembelajaran dan bahan ajar itu sendiri dimana buku paket yang disediakan di sekolah masih belum mencukupi secara menyeluruh sehingga ada beberapa peserta didik yang memegang satu buku paket untuk dua orang. Selain keterbatasan buku paket peserta didik juga belum memiliki bahan ajar bantuan berupa LKPD/ LKS.

Berdasarkan analisis lapangan peneliti juga mendapatkan sejumlah masalah yang ditemukan dalam pembelajaran narrative text. Kebanyakan dari peserta didik masih menghadapi kesulitan dalam mempelajari konsep narrative text. Kondisi ini dikarenakan kurangnya minat belajar dari peserta didik terhadap pembelajaran Bahasa Inggris kemudian peserta didik tidak terbiasa untuk memahami dan mempelajari terlebih dahulu materi prasyarat yang akan dipelajari. Saat berlangsungya pembelajaran peserta didik terbiasa memperhatikan, mendengarkan dan mencatat apa yang disampaikan guru sehingga terlihat kurangnya keaktifan dari peserta didik. Kurangnya kegiatan peserta didik dalam belajar mengakibatkan proses berpikir mereka menjadi lebih rendah hal ini dibuktikan ketika peneliti memberikan sebuah soal sederhana, cuma sejumlah dari peserta didik yang mampu menjawab sedangkan sebagian lainya dari mereka masih mengharapkan jawaban dari teman. Jika soal ditukar dengan cara yang berbeda peneliti mengamati peserta didik sulit akan menganalisis dan kebanyakan bingung serta sering bertanya kepada guru tanpa mencoba terlebih dahulu.

Untuk itu, peneliti merancang sebuah LKPD yang bisa dipakai oleh peserta didik dalam belajar baik secara pribadi ataupun kelompok. Disamping itu LKPD berbasis $D B L$ ini akan memberi pengetahuan langsung kepada peserta didik melalui berbagai aktivitas eksperimen di dalam LKPD. Hal ini diharapkan dapat merangsang kemampuan HOTS peserta didik serta memotivasi agar berkontribusi aktif dalam belajar. Selain itu diharapkan mampu menanggulangi masalah yang dihadapinya karena dalam LKPD ini mereka dituntut untuk menemukan konsep secara mandiri ataupun kelompok melalui eksperimen sesuai dengan materi yang dipelajari.

\section{Hasil Analisis Silabus Bahasa Inggris Kelas XI MAN Kota Sorong}

Merujuk pada KI dan KD yang terdapat pada Tabel yang sudah dipaparkan sebelumnya. dari masing - masing materi pokok tersebut peneliti melakukan analisis terhadap silabus Bahasa Inggris Kelas XI. Pada penelitian ini peneliti mengembangkan materi narrative text menjadi beberapa sub materi yaitu (1) fungsi sosial teks, (2) struktur teks dan (3) unsur kebahasaan. Pada penelitian ini peneliti mengalokasikan untuk 3x pertemuan dengan waktu 2 x 45 menit. Untuk materi momentum dan impuls peneliti mengembangkan menjadi beberapa sub materi yaitu (1) fungsi sosial teks, (2) struktur teks dan (3) unsur kebahasaan. Pada penelitian ini peneliti mengalokasikan untuk 3x pertemuan dengan waktu 3 x 45 menit. Sedangkan pada materi getaran harmonis peneliti mengembangkan menjadi 2 sub materi yaitu (1) fungsi sosial teks dan (2) struktur teks. Pada penelitian ini peneliti mengalokasikan untuk $2 \mathrm{x}$ pertemuan dengan waktu 2 x 45 menit.

Dari 3 kompetensi dasar tersebut mengkondisikan peserta didik untuk menganalisis dan melaksanakan penyelidikan dan ini sangat cocok digunakan untuk strategi Discovery Based Learning $(D B L)$, karena pada kompetensi dasar selain menganalisis yang merupakan indikator HOTS (C4) selanjutnya juga melakukan percobaan yang merupakan salah satu langkah langkah dari strategi $D B L$. Jadi berdasarkan analisis tersebut peneliti lakukan KD ini sesuai dengan pengembangan LKPD yang peneliti harapkan. 


\section{Hasil Analisis Buku Paket Bahasa Inggris Kelas XI IPS yang Tersedia di Sekolah}

Hasil analisis buku paket yang digunakan oleh guru Bahasa Inggris Kelas XI IPS MAN Kota Sorong yaitu Buku Siswa Kajian Konsep Bahasa Inggris untuk Kelas XI SMA dan MA sesuai. Buku karangan dari Nur Wulansari, dkk yang diterbitkan pada tahun 2016. Berdasarkan analisis buku paket tersebut peneliti menemukan beberapa kelemahan yang di memiliki oleh buku itu diantaranya :

1.Buku ini memuat materi dan cara penyajian yang tidak sesuai dengan karakteristik peserta didik. Hasilnya kebanyakan dari peserta didik kesulitan memahami isi buku tersebut. 2.Buku ini lebih mengutamakan materi dan soal - soal yang lebih memformulasikan rumus secara langsung 3.Lebih mengutamakan konsep - konsep Bahasa Inggris 4.Kurangnya kegiatan.

\section{Hasil Analisis Peserta Didik}

Analisis karakteristik peserta didik yang dimaksud adalah untuk mengetahui kondisi dan kebutuhan peserta didik di dalam pembelajaran, sehingga LKPD yang dirancang tepat sasaran sesuai dengan karakteristik peserta didik Kelas XI IPS MAN Kota Sorong. Merujuk dari hasil wawancara yang dilakukan dengan peserta didik Kelas XI IPS MAN Kota Sorong, menjelaskan bahwa peserta didik lebih tertarik dengan LKPD bergambar dan berwarna dan mereka lebih tertarik lagi jika belajar dalam suasana yang tidak menegangkan, seperti: diskusi, praktikum dan presentasi. Selama proses pembelajaran, peneliti juga mengamati cara belajar peserta didik dan hasil pengamatan ini menunjukkan bahwa peserta didik terbiasa dengan metode konvesional dimana guru berperan aktif ketimbang peserta didik. Selain itu di dalam pembelajaran yang sedang berlangsung peserta didik terbiasa menerima dan mencatat dari apa yang disampaikan guru, namun ada juga dari mereka yang belajar dengan baik jika terdapat demontrasi yang diberikan baik itu dari guru ataupun dari temanya sendiri. Perbedaan gaya belajar visual tentu akan berbeda dengan gaya belajar auditori yang mengedepankan kemampuan pendengaranya, selanjutnya bagi mereka yang gaya belajar kinestetik lebih mengedepankan belajar dengan terlibat langsung. Selain itu, tingkah laku dan minat peserta didik ini menjadikan sumber belajar harus menarik dan memotivasi mereka untuk belajar. Perbedaan kecepatan belajar juga menjadi karakteristik peserta didik MAN Kota Sorong, dimana peserta didik di dalam satu kelas memiliki kecepatan belajar yang berbeda, ada yang rendah, sedang dan tinggi. Sehingga sumber belajar harus menyesuaikan dengan tingkat penguasaan peserta didik. Oleh karena itu, diperlukan sumber belajar yang sesuai dengan karakteristik peserta didik Kelas XI IPS sekaligus menarik dan sesuai dengan tingkat penguasaan mereka. Sehingga mampu menjadikan peserta didik belajar mandiri dan bisa menyesuaikan dengan perkembangan ilmu pengetahuan dan teknologi.Hasil Analisis Literatur Tentang LKPD

Bahan ajar berupa LKPD ini memuat serangkaian lembaran kegiatan yang disusun secara sistematis dalam rangka mempermudah tercapainya tujuan pembelajaran. Dengan adanya LKPD dapat menunjang belajar sekaligus menjadikan peserta didik belajar lebih aktif karena di dalam LKPD terdapat serangkaian kegiatan yang mesti diikuti oleh peserta didik. Pemberian informasi pendukung dan tugas yang berkaiatan dengan materi yang dipelajari, membuat aktivitas pembelajaran mereka lebih terarah sehingga pembelajaran lebih efektif dan efisien. LKPD berbasis $D B L$ yang dilengkapi soal HOTS dirancang dan dikembangkan berdasarkan format baku penulisan LKPD. Pemaparan tahapan pembelajaran $D B L$ telah disusun di dalam LKPD. Secara umum susunan LKPD terdiri dari : 1) cover, 2) kata pengantar, 3) sekilas info mengenai isi LKPD, 4) petunjuk belajar, 5) daftar isi, 6) standar isi yang memuat $\mathrm{KI}$ dan KD, 7) peta konsep, 8) indikator pembelajaran, 9) lembaran kegiatan peserta didik disetiap kali pertemuan yang disusun berdasarkan sintak $D B L, 10)$ ringkasan materi dan contoh soal, 11) sekilas info Bahasa Inggris, 12) latihan soal disetiap pertemuan, 13) evaluasi pada akhir bab, dan 14) kunci jawaban. 


\section{Hasil Perancangan LKPD Bahasa Inggris Berbasis $D B L$}

LKPD Bahasa Inggris berbasis $D B L$ dirancang dan dikembangkan untuk materi Narrative Text. LKPD ini didesain dengan perpaduan warna hijau tua dan hijau muda kemudian ditambah dengan memberikan background gambar disetiap lembaran LKPD. Di dalam penulisan LKPD peneliti menggunakan jenis huruf Time New Roman, dengan ukuran berkisar antara 12 - 18. Bahan ajar yang disajikan di dalam LKPD tidak diberikan secara langsung akan tetapi peserta didik dituntut untuk mencari dan menemukan sebuah konsep/ prinsip terlebih dahulu berdasarkan rumusan masalah yang diajukan melalui pendekatan model $D B L$. Pembelajaran dengan menggunakan model $D B L$ ini terdiri atas 6 tahapan yaitu tahap pemberian rangsangan (Stimulation), tahap identifikasi masalah (Problem Statement), tahap pengumpulan data (Data Collection), tahap pengolahan data (Data Processing), tahap pembuktian (Verification), tahap penarikan kesimpulan (Generalization).

Selain itu LKPD berbasis $D B L$ terdiri atas 3 bab. Untuk (1) fungsi sosial teks, (2) struktur teks dan (3) unsur kebahasaan. Disetiap bab terdiri atas beberapa kali pertemuan dimana bab 1 terdiri atas 3 kali pertemuan dilengkapi lembaran kegiatan belajar yang sesuai sub materi yang dipelajari, pada bab 2 terdiri atas 3 kali pertemuan dilengkapi lembaran kegiatan belajar yang sesuai dengan sub materi yang dipelajari, kemudian bab 3 terdiri atas 2 kali pertemuan dilengkapi lembaran kegiatan belajar yang juga sesuai sub materi yang dipelajari. Setiap lembaran kegiatan belajar peserta didik yang terdapat pada LKPD mengacu kepada langkah - langkah $D B L$. Untuk desain secara keseluruhan dari rancangan LKPD berbasis $D B L$. Secara struktural LKPD ini terdiri dari komponen - komponen yang di dalam kegiatan belajarnya mengacu kepada model $D B L$ sesuai dengan komponen LKPD yang diuraikan sebelumnya. LKPD ini dirancang menggunakan aplikasi Corel Draw19 dan Microsoft Word 2010. Berikut diuraikan karakteristik LKPD berbasis DBL. Cover LKPD Bahasa Inggris Berbasis $D B L$

\section{Hasil Perancangan Instrumen Penelitian}

Perancangan hasil instrument penelitian meliputi lembar validasi LKPD berbasis $D B L$, RPP, kisi - kisi angket respon praktikalitas guru dan peserta didik, dan lembar validasi angket praktikalitas responden. Angket respon praktikalitas guru dan peserta didik. Masing - masing lembar validasi tersebut digunakan untuk menilai kelayakan produk baik itu LKPD berbasis $D B L$, RPP dan angket respon yang dikembangkan dalam penelitian ini. Lembar validasi LKPD berbasis $D B L$ bertujuan untuk mengukur apakah LKPD yang dikembangkan sudah layak atau tidak dipergunakan. Sedangkan lembar validasi bertujuan mengukur layak atau tidaknya RPP sebagai pedoman (acuan) bagi guru di dalam menggunakan LKPD berbasis $D B L$. Sedangkan lembar validasi angket responden bertujuan mengetahui ketepatan atau tidaknya butir pertanyaan yang telah dirancang. Instrumen dibuat dalam bentuk angket daftar isian (check list). Angket ini berisi serangkaian pernyataan yang harus diisi oleh validator melalui google formulir yang sudah disiapkan. Untuk penilaian disetiap aspek penilaian disandarkan kepada panduan dan rubrik penskoran. Adapun penilaian berupa masukan, komentar dan saran dipakai untuk acuan dalam perbaikan nantinya.

\section{Develop (Pengembangan)}

LKPD, RPP dan Instrumen penilaian yang sudah dikembangkan terlebih dahulu di diskusikan dengan pembimbing. Kemudian untuk melihat layak atau tidak layaknya produk yang dibuat peneliti melakukan proses validasi. Validasi dilaksanakan oleh para ahli dalam bidangnya (validator) dengan jumlah validator 3 orang diantaranya satu ahli materi (dosen), satu ahli media (dosen) dan satu guru yang berpengalaman dalam pengajaran Bahasa Inggris yaitu Ibu Venny Haris, M.Pd, Ibu Sri Maiyena, S.Pd, M.Pd dan Masjono, M.Pd. Berikut diuraikan hasil kegiatan pada tahap pengembangan diantaranya : 


\section{Hasil Validasi LKPD Berbasis DBL Dilengkapi Soal HOTS}

Data hasil validasi LKPD berbasis $D B L$ bisa dilihat secara lengkap. Berikut diuraikan hasil presentase dari hasil validasi untuk setiap indikator pernyataan pada masing - masing aspek.

Tabel 1. Rekapitulasi Hasil Validasi LKPD Berbasis $D B L$

\begin{tabular}{|l|c|c|c|c|c|c|c|}
\hline \multirow{2}{*}{ Aspek } & \multicolumn{3}{|c|}{ Validator } & \multirow{2}{*}{ Jml } & $\begin{array}{c}\text { Skor } \\
\text { Maks }\end{array}$ & $\%$ & Ket \\
\cline { 2 - 7 } & 1 & 2 & 3 & & 180 & 76,11 & Valid \\
\hline Isi LKPD & 47 & 45 & 45 & 137 & 180 & Valid \\
\hline Format LKPD & 29 & 27 & 33 & 89 & 108 & 82,41 & Sangat Valid \\
\hline Bahasa LKPD & 18 & 18 & 20 & 56 & 72 & 77,78 & Valid \\
\hline$\sum$ Jumlah & 94 & 90 & 98 & 282 & 360 & 78,33 & Valid \\
\hline
\end{tabular}

Berdasarkan memperlihatkan bahwa hasil validasi LKPD berbasis $D B L$ untuk setiap aspek berkisar antara 76,11\% sampai $82,41 \%$. Secara keseluruhan LKPD Bahasa Inggris berbasis $D B L$ tergolong valid dengan rata - rata persentase $78,33 \%$.

\section{Hasil Validasi Rencana Pelaksanaan Pembelajaran (RPP)}

Peneliti menggunakan lembar validasi untuk memperoleh RPP yang valid. Lembaran yang berisi beberapa aspek diberikan kepada validator untuk dinilai, aspek tersebut meliputi : (1) kesesuaian RPP dengan KI, (2) Indikator mengacu pada KD, (3) Kesesuaian urutan penyajian materi, (4) Ketepatan waktu, (5) Indikator mudah diukur, (6) Indikatornya mengandung kata - kata operasional, (7) Kegiatan guru dan peserta didik dirumuskan secara jelas, (8) Memenuhi bentuk baku penelitian sebuah RPP, (9) Kebenaran tata bahasa serta kesederhanaan struktur kalimat dan lain sebagainya.

\section{Terhadap LKPD Bahasa Inggris Berbasis $D B L$}

Hasil Validasi Angket Respon Praktikalitas Guru Terhadap LKPD Bahasa Inggris Berbasis $D B L U n t u k$ mengetahui valid atau tidaknya angket respon guru yang peneliti sajikan terhadap pelaksanaan pembelajaran dengan menggunakan LKPD berbasis $D B L$ peneliti menyebarkan instrumen validasi angket kepada guru ke validator. Hasil analisis validasi angket respon guru secara garis besar disajikan pada :

Tabel 2. Hasil Analisis Validasi Angket Respon Guru

\begin{tabular}{|l|c|c|c|c|c|c|c|}
\hline \multirow{2}{*}{ Aspek } & \multicolumn{3}{|c|}{ Validtor } & Jml & Skor & $\%$ & Ket \\
\cline { 2 - 8 } & 1 & 2 & 3 & & Maks & & \\
\hline FormatAngket & 3 & 3 & 3 & 9 & 12 & 75 & Valid \\
\hline Bahasa yang digunakan & 6 & 6 & 6 & 18 & 24 & 75 & Valid \\
\hline Butir pertanyaan angket & 7 & 6 & 6 & 19 & 24 & 79,17 & Valid \\
\hline E Jumlah & 16 & 15 & 15 & 46 & 60 & 76,67 & Valid \\
\hline
\end{tabular}

Dari hasil validasi angket respon praktikalitas guru untuk format angket, bahasa yang digunakan, dan butir pernyataan terhadap LKPD berbasis $D B L$ berkisar antara 75 sampai 79,17 $\%$. Secara keseluruhan angket respon guru tergolong valid dengan rata - rata persentase 76,67 $\%$. Hasil validasi oleh validator ditampilkan dalam bentuk diagram batang dibawah ini

\section{Hasil Validasi Angket Respon Praktikalitas Peserta Didik Terhadap LKPD Bahasa Inggris Berbasis $D B L$}

Untuk mengetahui valid atau tidaknya angket respon peserta didik, peneliti menyebarkan lembar validasi angket respon ke validator. Analisis hasil validasi angket respon ini dapat diliht 
Vol. 1 No. 3 Desember 2021, e-ISSN : 2797-8842 | p-ISSN : 2797-9431

Tabel 3. Hasil Analisis Validasi Angket Respon Peserta Didik

\begin{tabular}{|l|c|c|c|c|c|c|c|}
\hline \multirow{2}{*}{ Aspek } & \multicolumn{3}{c|}{ Validtor } & Jml & Skor & $\%$ & Ket \\
\cline { 2 - 9 } & 1 & 2 & 3 & & Maks & & \\
\hline Format Angket & 3 & 3 & 3 & 9 & 12 & 75 & Valid \\
\hline Bahasa yang digunakan & 6 & 6 & 6 & 18 & 24 & 75 & Valid \\
\hline Butir pertanyaan angket & 6 & 6 & 6 & 18 & 24 & 75 & Valid \\
\hline$\sum$ Jumlah & 15 & 15 & 15 & 45 & 60 & 75 & Valid \\
\hline
\end{tabular}

Berdasarkan Tabel menunjukkan bahwa hasil validasi angket respon peserta didik untuk format angket, bahasa yang digunakan, dan butir pernyataan pada hasil validasi angket respon peserta didik terhadap praktikalitas LKPD berbasis $D B L$ untuk setiap aspek bernilai $75 \%$. Secara keseluruhan angket respon ini tergolong valid dengan persentase rata - rata $75 \%$. Hasil validasi oleh validator ditampilkan dalam bentuk diagram batang dibawah ini :

Tabel 4. Rekapitulasi Persentase Hasil Validasi Angket Respon Peserta Didik

\begin{tabular}{|c|c|c|c|}
\hline \multirow{3}{*}{ SKOR } & Format Angket & $\begin{array}{c}\text { Bahasa yang } \\
\text { digunakan } \\
2\end{array}$ & $\begin{array}{c}\text { Butir } \\
\text { pertanyaan } \\
\text { angket } \\
\end{array}$ \\
\cline { 2 - 4 } & 1 & 75 & 3 \\
\hline
\end{tabular}

\section{Tahap Praktikalitas}

Setelah semua bahan pengembangan berupa LKPD berbasis $D B L$, RPP dan angket respon divalidasi oleh validator dan dinyatakan layak digunakan sebagai bahan pembelajaran, kemudian dilanjutkan pada tahap praktikalitas untuk melihat kemudahan/ kepraktisan dalam penggunaan LKPD Bahasa Inggris berbasis $D B L$. Peneliti melakukan uji coba pada satu kelas yaitu Kelas XI IPS MAN Kota Sorong dengan jumlah peserta didik sebanyak 18 orang dan 2 orang guru mata pelajaran Bahasa Inggris. Penelitian ini dilakukan pada hari senin/ 02 November 2020 melalui via WhatsApp. Guru dan peserta didik dibagikan angket respon praktikalitas pembelajaran terhadap LKPD berbasis DBLmelalui link google froom.Penilaian uji coba pengembangan angket meliputi penampilan, isi/ materi pembelajaran, bahasa dan keterbacaan dalam menggunakan LKPD. Angket yang digunakan berjumlah 18 angket praktikalitas untuk peserta didik dan 2 angket praktikalitas untuk guru dengan rentang skor 1 4.

\section{Analisis dan Hasil Angket Respon Guru Terhadap Praktikalitas LKPD Bahasa Inggris Berbasis $D B L$}

LKPD berbasis $D B L$ beserta RPP yang sudah divalidasi diserahkan kepada guru Bahasa Inggris Kelas XI MAN Kota Sorong dalam bentuk $p d f$. Metode ini dilakukan secara daring melalui via WhatsApp. Untuk mengetahui praktis atau tidaknya produk yang dikembangkan peneliti menyebarkan link angket respon praktikalitas guru dengan menggunakan google form. Hasil dari angket respon praktikalitas guru dapat dilihat pada Lampiran XIV. Analisis dan hasil angket respon praktikalitas guru dapat dilihat pada penilaian persentase guru terhadap LKPD berbasis $D B L$ di setiap pertanyaan angket respon berkisar antara $75 \%$ hingga 87,5\%. Secara keseluruhan jumlah persentase penilaian peserta didik terhadap LKPD berbasis $D B L$ adalah $86,54 \%$.

\section{Analisis dan Hasil Angket Respon Peserta Didik Terhadap Praktikalitas LKPD Bahasa Inggris Berbasis $D B L$}

Uji coba terbatas produk yang dilakukan pada peserta didik Kelas XI IPS MAN Kota Sorong dengan jumlah peserta didik 18 orang sebagaimana nama yang terlampir pada Uji coba ini dilakukan melaui metode daring dengan mengirimkan bahan penelitian melalui group 
whatsapp. Sebelum LKPD diterapkan, pembelajaran diawali dengan salam dan perkenalan diri. Peneliti memperkenalkan maksud dan tujuan dalam 1x pertemuan yang peneliti adakan, setelah itu dilanjutkan denganmembagikan LKPD Bahasa Inggris berbasis $D B L$ ke dalam group sekaligus memperkenalkan karakteristik dari LKPD berbasis $D B L$.

Berikutnya peneliti menginstruksikan peserta didik untuk membaca dan memperkenankan menggunakan salah satu materi yang ada pada LKPD untuk dikerjakan. Disini peserta didik sepakat memahami dan mencoba menggunakan LKPD berbasis $D B L$ pada materi getaran harmoni. Setelah akhir pembelajaran peserta didik diminta respon dengan mengisi angket melalui link google form yang peneliti sebarkan. Penilaian ini dilakukan dengan memberikan tanggapan terhadap beberapa pertanyaan yang sudah tersedia pada angket tersebut. Analisis hasil angket respon praktikalitas peserta didik setelah menggunakan LKPD berbasis $D B L$. Presentase penilaian peserta didik terhadap LKPD berbasis $D B L$ di setiap pertanyaan angket respon berkisar antara 87,5\% hingga 95,83\%. Secara keseluruhan jumlah persentase penilaian peserta didik terhadap LKPD berbasis $D B L$ adalah 91,18 \%. Sebagaimana Penelitian terdahulu yang berjudul "Penggunaan Metode Discovery Based Learning Untuk Meningkatkan Keaktifan Dan Kompetensi Peserta Didik Pada Mata Pelajaran Perawatan Kelistrikan Kendaraan Ringan Kelas XI TKR 3 Di SMK Negeri 2 Yogyakarta". Diperoleh bahwa hasil terjadinya peningkatan kompetensi dan keaktifan belajar peserta didik melalui penerapan pembelajaran Discovery Based Learning $(D B L)$. Dilihat dari kenaikan siklus I ke siklus II yang dilakukan diantaranya : (1) Meningkatnya keaktifan belajar peserta didik dari 40.13\% - 76.16\% (2) Meningkatnya rata - rata nilai ketuntasan belajar peserta didik dari $75.74 \%-87.33 \%$ (3) Nilai ketuntasan belajar peserta didik pada kompetensi kognitif dari $67.74 \%-93.33 \%$.

\section{KESIMPULAN}

Penelitian dan pengembangan LKPD Bahasa Inggris berbasis $D B L$ yang dilengkapi soal $H O T S$ pada materi Narrative Text telah direalisasikan sesuai dengan tahapan $R \& D$. Perolehan hasil penelitian LKPD berbasis $D B L$ disimpulkan bahwa hasil validasi terhadap LKPD Bahasa Inggris berbasis $D B L$ yang dilengkapi soal HOTS peserta didik Kelas XI MAN Kota Sorong yang dikembangkan menunjukkan hasil yang valid dengan persentase $78,33 \%$ ditinjau dari aspek validitas isi, validitas format dan validitas bahasa yang digunakan di dalam LKPD. Validasi ini dilakukan oleh tiga orang validator yang terdiri atas dua orang dosen Bahasa Inggris dan satu orang guru bidang studi Bahasa Indonesia.Hasil praktikalitas terhadap LKPD Bahasa Inggris berbasis $D B L$ yang dikembangkan menunjukkan hasil praktikalitas pendidik dan praktikalitas peserta didik menunjukkan hasil yang praktis dan sangat praktis dengan persentase berturut-turut 75,96\% dan 91,18\%. Uji praktikalitas dilakukan pada guru Bahasa Inggris dan peserta didik Kelas XI IPS MAN Kota Sorong.

\section{DAFTAR PUSTAKA}

Abu Ahmadi dan Joko Tri Prasetyo. 2005. Strategi Belajar Mengajar. Bandung : Pustaka Setia Agustina Nelmi, dkk. 2019. Pengembangan Modul Berbasis Pembelajaran CTL Untuk Mencapai HOTS Pada Materi Getaran Harmonis. Jurnal FTIK IAIN Batusangkar iCoE-4. September 25-26, 2019. Diakses 20 Januari 2021

Ahmad Sabri. 2010. Srategi Belajar Mengajar Micro Teaching. Jakarta : PT Ciputat Press

Annisa Dira Ayu, dkk. 2016. Pengembangan LKS Pada Materi Teori Tumbukan Berbasis Discovery Learning. Jurnal Pendidikan dan Pembelajaran Kimia, Vol. 5, No.1 Edisi April 2016, 128-139. Diakses 1 Maret 2020

Arifin Zainal. 2012. Evaluasi Pembelajaran. Jakarta : Direktorat Jendral Pendidikan Islam Arsyad Azhar. 2011. Media Pengajaran. Jakarta : Pt. Raja Grafindo Persada

Berbasis Discovery Learning Pada Materi Elastisitas Dan Hukum Hooke Untuk Kelas XI SMA.Artikel Ilmiah pdf, diakses 5 Desember 2019

Budsankom, Prayoonsri, et al. 2015. Factors Affecting Higher Order Thinking Skills of Students: A Meta-Analytic Structural Equation Modeling Study. Academic Journals. 
Vol. 10 No. 19: 2639-2652. Diakses 1 Maret 2020

Hardiono dan Nuor Aini. 2016. Penerapan Model Pembelajaran Discovery Learning Untuk Meningkatkan Motivasi Dan Hasil Belajar Siswa Kelas VIII-d SMP 2 Kamal Materi Cahaya. Jurnal Pena Sains, Vol. 3, No. 2 Oktober 2016, p-ISSN : 2407-2311 dan eISSN : 2527-7634. Diakses 1Maret 2020

Herlanti Yanti. 2014. Tanya Jawab Seputar Penelitian Pendidikan Sains. Jakarta : Universitas Syarif Hidayatullah

Matondang Zulkifli. 2009. Validitas Dan Reabilitas Suatu Instrumen Penelitian.Jurnal Tabularasa PPS UNIMED. Vol. 6. No. 1, Juni 2009

Muhibin Sukardi. 2008. Evaluasi Pendidikan Prinsip Dan Operasionalnya. Yogyakarta : Bumi Aksara

Munthe Emy Maria Septiani dan Juru Bahasa Sinuraya. 2019. Uji Layak Lembar Kerja Peserta Didik (LKPD) Berbasis Discovery Learning Pada Materi Momentum dan Impuls. Jurnal Ikatan Alumni Bahasa Inggris Universitas Negeri Medan, Vol. 5, No. 3, JuliSeptember, ISSN : 2461-1247. Diakses 1Maret 2020

Nadhiroh Nuraini. 2018. Pengembangan Lembar Kerja Peserta Didik (LKPD) Berbasis Higher Order Thinking Skills (HOTS) Pada Materi Termodinamika. Pdf, diakses 5 Desember 2019

Nisa Nur Choerun, dkk. 2018. Kemampuan Berpikir Tingkat Tinggi (HOTS) Tentang Lingkungan Berdasarkan Latar Belakang Akademik Siswa. Jurnal Pendidikan Lingkungan dan Pembangunan Berkelanjutan, Vol. XIX, No. 2, Spetember 2018, eISSN : 2580-9199. Diakses 25 Januari 2021

Pardede Erna, dkk. 2016. Efek Model Pembelajaran Guided Discovery Berbasis Kolaborasi Dengan Media Flash Terhadap Keterampilan Proses Sains Dan Hasil Belajar Kognitif Tinggi Bahasa Inggris Siswa SMA. Jurnal Pendidikan Bahasa Inggris, p-ISSN 2252732X, e-ISSN 2301-7651. Diakses 5 Desember 2019

Permendikbud, No 37 Tahun 2018 Tentang "Perubahan Atas Peraturan Menteri Pendidikan dan Kebudayaan Nomor 24 Tahun 2016 Tentang Kompetensi Inti dan Kompetensi Dasar Pelajaran pada Kurikulum 2013 pada Pendidikan Dasar dan Pendidikan Menengah”. Jakarta. Pdf diakses 14 Desember 2020

Permendikbud, No 65 Tahun 2013 Tentang "Standar Proses Pendidikan Dasar dan Menengah”. Jakarta. Pdf diakses 14 Desember 2020

Pramono, Doni setiawan. 2018. Penggunaan Metode Discovery Learning Untuk Meningkatkan

Keaktifan Dan Kompetensi Siswa Pada Mata Pelajaran Perawatan Kelistrikan Kendaraan Ringan Kelas XI TKR 3 Di SMK Negeri 2 Yogyakarta. Jakarta : Universitas Negeri Yogyakarta. Pdf, Diakses senin, 27 Januari 2020

Prastowo Andi. 2012. Panduan Kreatif Membuat Bahan Ajar Inovatif. Yogyakarta : Diva Press PT. Remaja Rosdakarya : Bandung

Rahman Risqi dan Samsul Maarif. 2014. Pengaruh Penggunaan Metode Discovery Terhadap Kemampuan Analogi Matematis Siswa SMK Al- Ikhsan Pamarican Kabupaten Ciamis Jawa Barat. Jurnal Ilmiah Program Studi Matematika STKIP Siliwangi Bandung, Vol. 3, No.1, Februari 2014. Diakses 1 Maret 2020

Ramadhan Katon Agung. dkk. 2018. Pengembangan Lembar Kerja Peserta Didik Berbasis Hots Dengan Discovery Learning Pada SMA Kelas XI. Pdf, diakses 5 Desember 2019 Riduwan. 2005. Belajar Mudah Penelitian. Jakarta : Alfabeta

Rochman Syaiful dan Zainal Hartoyo. 2018. Analisis High Order Thinking Skills (HOTS) Taksonomi Menganalisis Permasalahan Bahasa Inggris. Jurnal Science and Physics Education Journal (SPEJ), Volume 1, No. 2, Juni 2018, e-ISSN : 2598-2567, p-ISSN : 2614-0195. Diakses 17 Maret 2020

Roestiyah. 2012. Strategi Belajar Mengajar. Jakarta : PT Rineka Cipta

Sanjaya, Wina. 2006. Strategi Pembelajaran Berorientasi Standar Proses Pendidika. Jakarta : Kencana 
Saparno Paul. 2013. Metodologi Pembelajaran Bahasa Inggris. Yogyakarta : Universitas Sanata Dharma

Sugiyono. 2013. Metode Penelitian Kuantitatif dan R\&D. Bandung : Alfabert Sulistia Heny. 2017. Pengembangan Lembar Kerja Peserta Didik (LKPD) Bahasa Inggris

Supriano. 2018. Buku Penilaian Berorientasi HOTS. Jakarta : Direktorat Jenderal Guru dan Tenaga Kependidikan

Suryani Nunuk, dkk. 2018. Media Pembelajaran Inovatif Dan Pengembangannya.

Suyono dan Harikunto. 2012. Belajar Dan Pembelajaran. Bandung : PT. Remaja Rosdakarya

Trianto. 2009. Mendesain Model Pembelajaran Inovatif Progresif. Jakarta : Kencana Prenada Media Group

Trianto. 2011. Model Pembelajaran Terpadu: Konsep, Strategi dan Implementasinya Dalam Kurikulum Tingkat Satuan Pendidikan (KTSP). Jakarta : Bumi Aksara

Widana, I Wayan. 2017. Modul Penyusunan Soal HOTS. Jakarta : Direktorat Pembinaan SMA Ditjen Pendidikan Dasar dan Menengah 